\title{
河川流域の流水水温形成における 基底流出水温の影響について \\ ON THE INFLUENCE OF BASE FLOW TEMPERATURE ON STREAM TEMPERATURE FORMATION IN A RIVER BASIN
}

\author{
浦野仁志 1 ・宮本仁志 2 ・前羽 洋 3 - 戸田祐嗣 4 \\ Hitoshi URANO, Hitoshi MIYAMOTO, Hiroshi MAEBA and Yuji TODA \\ 1学生会員 神戸大学大学院工学研究科市民工学専攻博士課程前期課程 ( T657-8501 神戸市灘区六甲台町1-1) \\ 2正会員 博士(工学) 神戸大学大学院准教授 工学研究科市民工学専攻 ( 同上 ) \\ 3正会員 修士(工学) 前 神戸大学大学院学生 (現 JFEエンジニアリング(株)) ( 同上 ) \\ 4正会員 博士(工学) 名古屋大学大学院准教授 工学研究科社会基盤工学専攻( ( 464-8603 名古屋市千種区不老町)
}

\begin{abstract}
This paper investigates influence of base flow discharge on stream temperature formation in a river network for refining a stream temperature network model. A base flow temperature at a spring water spot has been observed for several years in Ibo River Basin in Japan. The data indicate that there is a time delay with a few months in the peak temperatures between the surface flow and base flow, so that the base flow could give higher temperature input into the stream water body in winter and lower input in summer. A newly proposed base flow temperature model with the stream temperature network model shows very high prediction ability for the temperature distribution structures along the river network for all seasons.
\end{abstract}

Key Words: river basin management, river temperature, heat budget, stream network, groundwater, cooling season

\section{1. 序論}

流域の河川地先は水系ネットワークにより流域全体と つながり，そのネットワーク上で水やエネルギー・物質 が循環され，生態系の代謝やヒトの社会活動が支えられ る. したがって，河川環境管理を行う際にも，河川流域 の代謝能を考慮し, 河川地先と流域全体との連関性を陽 に扱った，持続可能な流域一貫の方策が望まれる.

筆者らは，この流域一貫の観点から河川環境管理を支 援するツールを開発するために，河川水温を対象にして 流域スケールでの観測と解析を行ってきた ${ }^{1-9)}$. 本研究で 提案する河川水温のネットワークモデル ${ }^{1,3,7)}$ は, 各河道 の水温変化を位数則 ${ }^{10-12}$ により関連づけて定式化するも のである. モデルでは水系ネットワークのつながりに 従って源流から河口へと計算が進められる. 各河道の上 流端の水温を境界条件として熱輸送方程式により下流端 の水温が推定される. 推定された下流端水温が次の河道 での境界条件に使われ，最終的に水系全体の河川水温が 推定される.

前報1)ではネットワークモデルの精緻化を検討した. 正規化植生指数 NDVI(Normalized Difference Vegetation
Index)を用いて日射遮蔽の季節変化を表現し，降水量と 地質分布を考慮したリンクマグニチュード12)による流量 推定モデル $\left.{ }^{13}\right)$ 導入した. その結果，水面からの受熱が 卓越する春〜夏期において本モデルは十分な精度で河川 水温の流域分布を再現することが確認された。 しかしな がら，放熱の卓越する秋〜冬期の水温予測に関してはモ デルの改善余地が残された.

河川水温は，農業用水や工場の冷却水など水資源とし て重要になるとともに，河川生態系に非常に大きな影響 を及ぼす ${ }^{14-16)}$. 河川水温に関する既往の研究は多く, 上

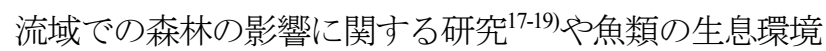
に関する研究 ${ }^{20)}$, 気候変動に関する研究4,21,22)などが挙げ られる。しかしながら，それらの多くは上流部小流域や 河川地先を対象とした研究であり, 本研究のように水系 ネットワーク構造を導入して河川流域全体を対象とした 研究事例は少ない.

本論文では，放熱期の水温予測精度の改善を図るため に，地下水・湧水など基底流出の水温変動特性を観測事 実より検討する。 それより，基底流出水温の季節変動特 性を考慮した横流入水温の数理モデルを構築する. 提案 する横流入水温のモデルを河川水温のネットワークモデ ルに導入し，河川水系全体の観測水温を用いてモデルパ 


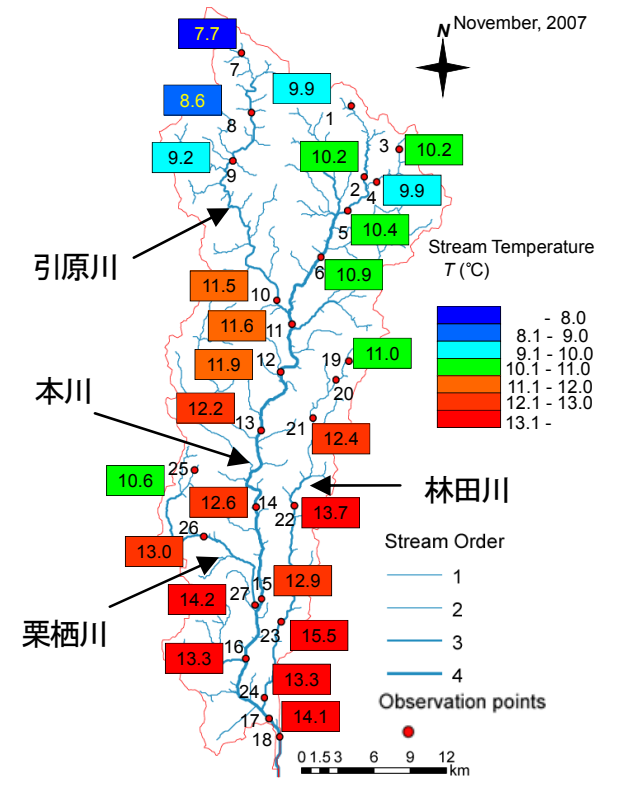

図-1 揖保川流域の河道網・観測点および2007年11月の月 平均水温 (揖保川本川(観測点No. 1-2, 5-6, 11-18), 引原 川(№. 7-10)， 林田川(№. 19-24)，栗栖川(№. 25-27))

ラメーターの最適值を同定する，得られたモデルより， 基底流出水温が河川水系全体の水温形成に及ぼす影響を 検討する. 最後に, 本論文で得られた成果を纏めるとと もに，今後の課題や研究の方向性に言及する.

\section{2. 対象流域}

\section{(1) 揖保川の概要}

ネットワークモデルを検証するための試験流域は兵庫 県南西部に位置する一級水系揖保川流域 8 (゙ある. 図-1 に揖保川流域の河道網，観測点，および2007年11月にお ける月平均水温の流域分布を示す。水温観測は2006年5 月から継続されており，流域内27地点に設置したプロー ブによって水温データが1時間毎に自動計測される ${ }^{8)}$. 同 流域は南北に長い形状をもち，揖保川本川(観測点No.1-2, 5-6,11-18) と主な支川である引原川(No.7-10)・林田川 (No.19-24)・栗栖川(No.25-27)などから構成される.また， 林田川の観測点No.20は，後述のように水温の変動特性 が他の観測点のものと異なり, 地下からの湧水が計測さ れていると考えられる.

図-1の月平均水温より，上流から河口へ向けて水温が 上昇していく様子が確認できる．同流域では年間を通じ てこのような流下に伴う昇温傾向が見られる. 図-1に示 す2007年11月では，上下流間(No.7-No.17)の昇温は6.4 ${ }^{\circ} \mathrm{C}$ である。これまでの観測から揖保川流域では最大昇温は 8 月の約 $9^{\circ} \mathrm{C}$, 最小昇温は 1 月の約 $4^{\circ} \mathrm{C}$ なる. なお，本論 文では，2006年から現在までのデータセットのうち， 2007年のものを対象として検討を行う.

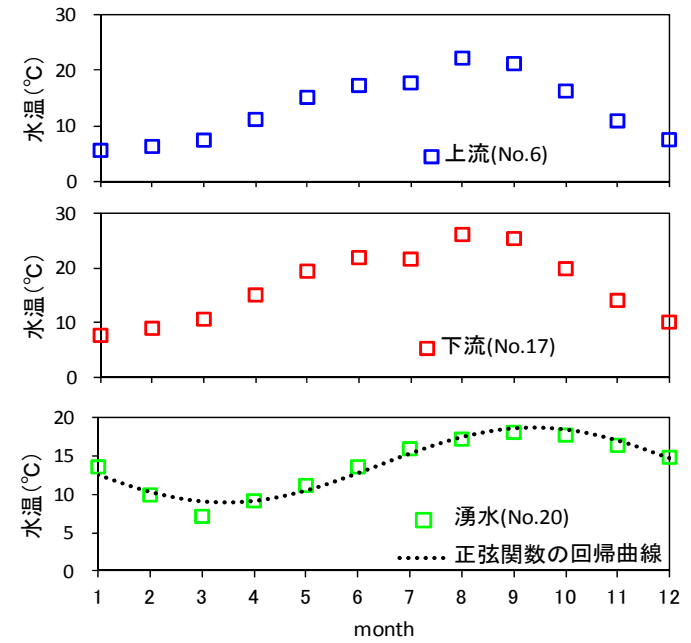

図-2 月平均水温の時系列(2007年)

\section{（2）湧水水温の変動特性}

図-2に，上述の林田川No.20の湧水地点と本川の上・ 下流の観測点 (No.6,No.17)における月平均水温時系列 (2007年)を示す. 図中, 湧水温には正弦関数を用いた回 帰曲線を併示した。図より湧水地点の水温は他地点に比 ベ最高水温と最低水温のピークが 1 2 个月程度遅れるこ とがわかる. また, 湧水水温の年較差は $10^{\circ} \mathrm{C}$ 前後である のに対して，他地点では $15 〜 20^{\circ} \mathrm{C}$ 前後である.このよう に, 湧水水温は他地点の水温に比べ水温変化に月才一 ダ一のタイムラグが発生し, 年較差も比較的低い值を示 す特徵がある.さらに，図に示すように湧水水温のデー 夕は回帰曲線でよく表現されており，正弦関数により湧 水・地下水など基底流出水温の年周変動をよく近似でき ることが推察される.

\section{3. 解析方法}

\section{（1）河川水温ネットワークモデルの概要}

本モデルでは，本節1)の河道位数則 ${ }^{10-12)}$ により表現さ れた水系ネットワーク上を源流から河口へ向けて, 河川 水温が推定される. 図-3に示すそれぞれの河道リンクで は，河川水塊が受ける熱フラックスが本節3)の熱輸送方 程式にて定式化され，それを解くことで河道リンク下流 端の水温が推定される. 推定された下流端水温が次の河 道での境界条件に使われ，最終的に水系全体の河川水温 が推定される.ここでは主に基礎方程式を示すが，詳細 なモデルの定式化は宮本ら ${ }^{7}$ に詳しく記載される. なお, 本モデルは河道ネットワーク構造に着目して流域におけ る環境インパクトの水系全体への影響評価を目指すため, 月単位の平均水温を解析対象としている.

\section{1）水系ネットワークのモデル(河道位数則)}

水系ネットワーク構造のモデル化では，河道の合・分 流構造を正確に表現するために, Shreveのリンクマグニ チュード $i^{12)}$ を用いる. その際, Hortonの河道位数則 ${ }^{11)}$ 


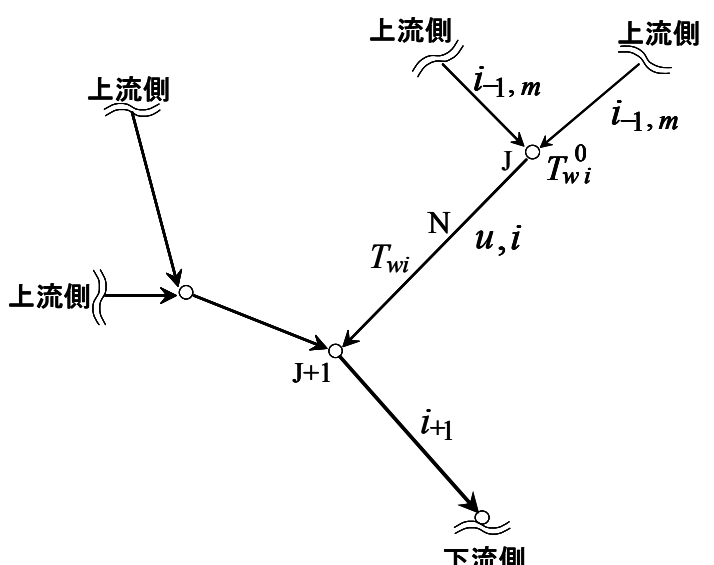

下流側

図-3 流域の一部における河道ネットワークの模式図

を介してリンクマグニチュード $i$ と流量, 河川幅など河 川水文・地形変数とを関連づける. 位数 $u$ を用いた河道 位数則, および $u$ と $i$ の関係は以下の式で表される ${ }^{1,3,7)}$.

$$
\begin{gathered}
N_{u}=R_{B}{ }^{k-u}, \quad R_{B}=N_{u-1} / N_{u} \quad \text { (河道数則) } \\
\overline{L_{u}}=\overline{L_{1}} R_{L}{ }^{u-1}, \quad R_{L}=\overline{L_{u}} / \overline{L_{u-1}} \quad \text { (河道長則) } \\
\overline{A_{u}}=\bar{A}_{1} R_{A}{ }^{u-1}, \quad R_{A}=\overline{A_{u}} / \overline{A_{u-1}} \quad \text { (流域面積則) } \\
\overline{S_{u}}=\bar{S}_{1} R_{S}{ }^{1-u}, \quad R_{S}=\overline{S_{u-1}} / \overline{S_{u}} \quad \text { (河道勾配則) } \\
\bar{i}_{u}=R_{B}{ }^{u-1} \quad(\text { (位数とマグニチュードの関係) }
\end{gathered}
$$

ここに, $N_{u}, \bar{L}_{u}, \bar{S}_{u}, \bar{A}_{u}, \bar{i}_{u}$ : それぞれ， $k$ 次流域内にお ける $u$ 次河道の河道数 $(1 \leq u \leq k)$, 平均河道長, 平均河 道勾配, $u$ 次流域の平均流域面積, マグニチュードの平 均值であり， $R_{B}, R_{L}, R_{A}, R_{S}$ : それぞれ，分岐比，河道 長比，流域面積比，河道勾配比である.

リンクマグニチュードとと関連付けられる諸量》は，流 量, 河川幅, 河道リンク長, 横流入量, 河道標高などが 挙げられる. 次項では, 流量・河川幅といった河川水文 量のリンクマグニチュードによよる数理表現を例示する.

2）河川水文量のリンクマグニチュードによる表現

a) 流量

流量の水系分布は，気候・地質の影響を考慮した推定 モデル(13)を用いる．リンクマグニチュード，集水域面積 $\overline{A_{i}}$ の流域において, ある生起確率に対応する河川流量 $\overline{Q_{i}}$ は, 次式のように与えられる.

$$
\begin{gathered}
\overline{Q_{i}}=a \cdot \bar{A}_{i}^{b} \\
=a \cdot \bar{A}_{1}^{b} \cdot i^{b \cdot \lambda} \\
a=\bar{r} \cdot\left(\sum_{\gamma} f_{p \gamma} \cdot G_{\gamma} / \bar{A}_{i}\right)^{b}
\end{gathered}
$$

ここに， $a$ : 降水量と地質の影響を考慮したモデル係数, $b$ : モデル指数, $\overline{A_{1}}$ : 一次流域 $(i=1)$ の平均集水域面積,

$\bar{r}$ : 各流域における年降水量, $f_{p \gamma}$ : 降水量・地質の影 響が反映されるモデル係数, $G_{\gamma}$ : 流域内の地質区分 $\gamma$ ごとの面積である， $\lambda$ は次式により与えられ，日本の一 級水系ではおおよそ $\lambda=1.1$ となる ${ }^{13)}$.

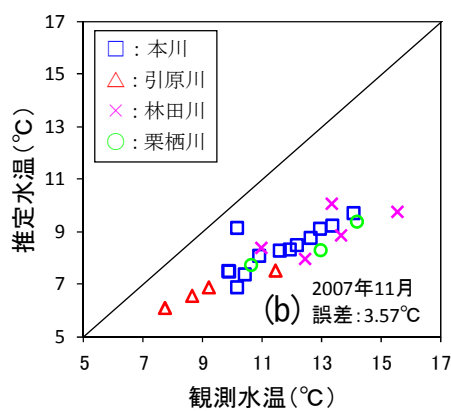

図-4 前報モデル1) での推定水温と観測水温の比較

$$
\lambda=\log R_{A} / \log R_{B}
$$

モデル係数・指数は, 相模川を除く 108 の一級水系に おける10年平均の河川流況から同定されている ${ }^{13)}$. した がって式(6) (8)により，10年平均流況の水系分布が与 えられることになる. 解析対象年の流量は, 式(7)の降水 量 $\bar{r}$ に当該年の降水量規模に対応する線形補正を施して 求められる.

\section{b) 河川幅}

河川幅 $B$ は既報 $1,3,7)$ と同じくレジム式で与えられる.

$$
B=c Q^{d}
$$

ここに, $c, d$ : 各流域・生起確率年毎に決定される係数と 指数である. 式(9)に式(6)を代入して係数を整理すると， リンクマグニチュード $i$ の河道における河川幅 $B_{i}$ は以 下のように与えられる.

$$
\begin{aligned}
B_{i} & =\left(c \cdot a^{d} \cdot \bar{A}_{1}^{b \cdot d}\right) \cdot i b \cdot \lambda \cdot d \\
& =\overline{B_{1}} \cdot i^{b \cdot \lambda \cdot d}
\end{aligned}
$$

ここに, $\overline{B_{1}}$ : 一次河道の平均河川幅である.

\section{3）河道リンク内の水温変化のモデル(熱輸送方程式)}

図-3に示寸各河道リンク内での水温変化は以下の一次 元熱輸送方程式の解析解》により与えられる.

$$
\begin{aligned}
& \underset{\text { 非定常垻 }}{\frac{\partial T_{w}}{\partial t}}=\frac{-V \frac{\partial T_{w}}{\partial x}}{=\frac{\frac{1}{A} \frac{\partial}{\partial x}\left(A D_{x} \frac{\partial T_{w}}{\partial x}\right)}{\text { 移流項 }}}=\frac{\frac{q_{x}}{A}\left(T_{w l}-T_{w}\right)}{\underline{\text { 㹡散項 }}} \\
& +\frac{\frac{1}{c_{w} \rho_{w} A} H_{w s} B}{\underline{\text { 水面熱制送項 }}}=\frac{\frac{1}{c_{w} \rho_{w} A} H_{b e d} P_{w}}{=} \\
& H_{w s}=\left(1-V_{S}\right) G_{S} H_{s}+H_{a}-H_{b r}-H_{l a}-H_{s e}
\end{aligned}
$$

ここに, $T_{w}$ : 河川水温, $V$ : 流下方向断面平均流速, $A$ : 流水断面積, $D_{x}$ : 水温の縦分散係数, $q_{x}$ : 横流入 量, $T_{w} l$ : 横流入水の水温, $c_{w}$ : 水の定圧比熱, $\rho_{w}$ : 水の密度, $H_{w s}$ : 水面からの熱フラックス, $H_{b e d}$ : 潤 辺からの熱フラックス, $B$ : 河川幅, $P_{w}$ : 潤辺長, $x$ : 流下方向座標, $t$ : 時間座標, $V_{S}$ : 河畔植生による遮蔽 率, $G_{S}$ : 地形による日射の補正係数, $H_{s}$ : 短波放射量, $H_{a}$ : 長波放射量, $H_{b r}$ : 長波逆放射量, $H_{l a}$ : 蒸発に 伴う潜熱量, $H_{s e}$ : 熱伝達に伴う顕熱量である. 
表-1 土地利用ごとのパラメータ 23

\begin{tabular}{|c|c|c|c|c|}
\hline 土地利用 & アルベド & 射出率 & バルク係数 & 蒸発効率 \\
\hline \hline 田 & 0.175 & 0.98 & 0.005 & 0.65 \\
\hline 農用地 & 0.215 & 0.95 & 0.003 & 0.3 \\
\hline 森林 & 0.15 & 0.98 & 0.005 & 0.2 \\
\hline 荒地 & 0.26 & 0.9 & 0.0015 & 0.5 \\
\hline 建物用地 & 0.22 & 0.96 & 0.005 & 0 \\
\hline 交通用地 & 0.12 & 0.96 & 0.0015 & 0 \\
\hline ゴルフ場 & 0.23 & 0.98 & 0.003 & 0.3 \\
\hline
\end{tabular}

本論文で検討する地下水・湧水などの基底流出水温は 横流入水の水温 $T_{w l}$ として与えられる.

式(11)の解析解の導出においては，前報1)と同様に月平 均河川水温の形成に支配的な因子は水面および河道上流 の熱フラックスと横流入水からの熱量であるとし，式 (11)中の非定常項, 拡散項, 潤辺熱輸送項の影響は小さ いと考えて無視した. ここで得られた河道リンク下流端 での解にその河道の流量を乗じて次の河道リンク上流端 の移流熱フラックスが算出される。前節の河道ネット ワークにそつて計算を進めていくことにより水系全体の 河川水温が推定される。

\section{4）計算の概要}

まず，分岐比 $R_{B}$ をはじめとする流域地形の特性量お よび各河道リンクのマグニチュード $i$ と河川ネットワー クの関連情報がGIS解析により算定される. 次に, 源流 $i=1 の$ 上流端で源流水温 $T_{0 j}{ }^{2}{ }^{2}$ が与えられ, 一次河道に おける熱輸送が計算される. 以下，順に河川ネットワー クに沿って河口 $i=i_{\max }$ に至るまで, 熱輸送方程式に基 づき各河道を移流していく熱フラックスが順次計算され， 各河道での河川水温が推定される.

\section{（2）基底流出水温の数理モデル}

図-4に前報モデル ${ }^{1)}$ による推定水温と観測水温の比較 を示す。ここでは前報1)のように一次河道の河川幅を最 適化せず一定值を与えて再計算した。 これより，2007年 5月の受熱期ではモデルの推定水温と観測水温は水系全 体で非常によく一致しているのに対し，2007年11月の放 熱期では推定水温が観測水温に比べてすべての地点で過 小評価されている，すなわち，放熱期では水系全体で河 道に与えられる熱フラックスが不足していることになる. この受熱フラックス不足の傾向は揖保川の放熱期である 10月～3月のすべての月で示される.

本論文では，これまで年平均の一定值を仮定して地温 平衡解 ${ }^{2}$ を与えていた横流入水温 $T_{w l}$ に関して，月才一 ダーの時間遅れをもつ基底流出水温を次式のようにモデ ル化して与える.

$$
T_{w l}=a \sin \left(b t_{m}+c\right)+T_{w l j}
$$

ここに, $t_{m}$ : 時刻(月単位)， $a, b, c$ : それぞれ, 基底 流出水温の振幅パラメーター, 周期パラメーター $(=\pi / 6$; 月単位), 位相パラメーター, $T_{w l j}$ : 各河道の集水域がも 年平均平衡地温. 後述の式(19))である. この横流入水 温のモデルは図-2に示すような2ヶ月程度の遅れ時間を もつ基底流出水温の河道流入を想定しているため，図一 4(b)に示される水系ネットワーク全般にわたる受熱つ ラックス不足を解消する方向に働くことが期待される. 式中のモデルパラメーター $a, c$ は観測水温を用いて同定 される.

式(13)の年平均平衡地温 $T_{w l i}$ の算出に必要な地表面熱 収支式は前報1,2) と同じく次式で与えた。

$$
\begin{gathered}
H g=\alpha(1-r e f) H_{s}+H_{a}-H_{b r}-H_{l a}-H_{s e} \\
H_{b r}=\varepsilon \sigma T_{g}^{4} \\
H_{l a}=\rho_{a} L_{l a} \beta C_{H} \frac{0.622}{p}\left[e_{s a t}\left(T_{g}\right)-e_{a}\right] W \\
H_{s e}=\rho_{a} c_{p} C_{H}\left(T_{g}-T_{a}\right) W
\end{gathered}
$$

ここに， $H_{g}$ : 地表面熱フラックス， $\alpha$ : 樹林による日 射の減衰率, ref : 土地利用ごとのアルベド, $\varepsilon$ : 射出 率， $\sigma$ : ステファン・ボルツマン定数, $T_{g}$ : 地表面温 度, $\rho_{a}$ : 空気密度, $L_{l a}$ : 蒸発に伴う潜熱量, $\beta$ : 蒸発 効率, $C_{H}$ : バルク係数, $p$ : 大気圧, $e_{a}, e_{s a t}$ : 水蒸気 圧及び飽和水蒸気圧, $W$ : 風速, $c_{p}$ : 空気の定圧比熱, $T_{a}$ : 気温, である. 表-1に, 本研究で用いた土地利用 ごとのパラメーター ${ }^{23)}$ を示す.

平衡地温 $T_{g e q}$ は熱的平衡状態にある地表面の温度で あり，次式を地表面温度に関して解くことにより与えら れる。

$$
H_{g}=0
$$

各河道の集水域がもつ年平均平衡地温 $T_{w l j}$ は，式(18) で得られる土地利用ごとの平衡地温 $T_{g e q L U}$ を土地利用 面積割合で重み付けして, 次式より算出した.

$$
T_{w l j}=\frac{\sum\left(T_{g e q L U} \times A_{j L U}\right)}{A_{j}}
$$

ここに, $A_{j}$ : 各河道の集水域面積, $A_{j L U}: A_{j}$ 中の各 土地利用面積である。

\section{4. 結果と考察}

\section{（1）基底流出水温のモデルパラメータ一同定}

式(13)のモデルパラメーター $a, c$ を放熱期における観 測水温と推定水温の二乗誤差が最小になるように求めた. 図-5にパラメーター $a, c$ の変化に伴う観測值と推定值の 平均誤差分布を示す。困の縦軸の振れ幅は，河川表流水 に対して基底流出のピーク水温がおおよそ1〜 5力月程度 の遅れ時間をもつことに対応する. これより, 最適值と して振幅パラメーター $a=7.31$ ，位相パラメーター $c=1.98$ が同定される. これは，流域全体として基底流 出水温が約 $14^{\circ} \mathrm{C}$ 年較差をもち, 基底流出のピーク水温 が約 3 ケ月の遅れ時間をもつことを示している.この年 較差とピークの遅れ時間は，図-2で示した湧水地点の水 温変動特性とほぼ同じ值となる。これより，式(13)のモ 


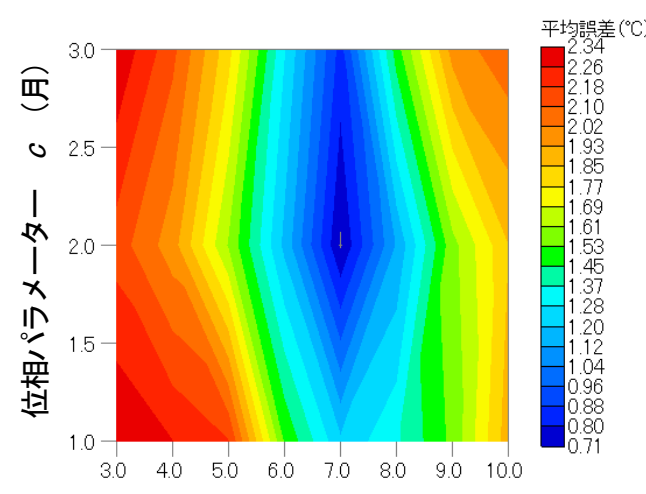

振幅パラメーター $a \quad\left({ }^{\circ} \mathrm{C}\right)$

図-5 パラメーター $\mathrm{a}, \mathrm{c}$ 感度分析

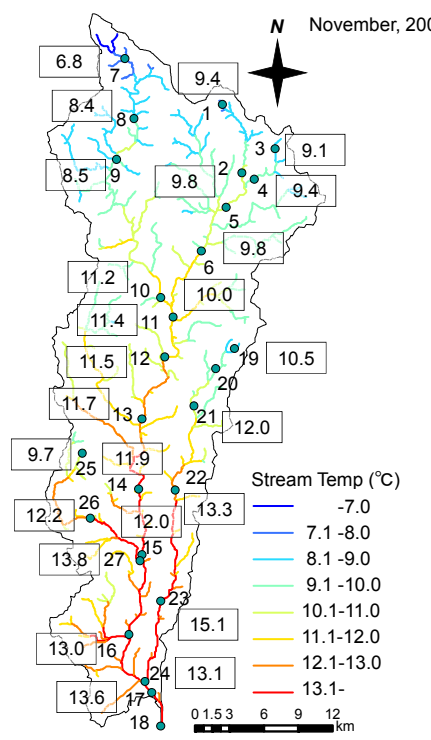

図-6 推定水温分布(2007年11月)

デルは基底流出水温をよく表現していることが推察され る.

各河道での横流入水温 $T_{w l}$ の季節変化は式(13)の正弦 回帰の部分で，一方，空間変化は各河道の集水域がもつ 年平均平衡地温 $T_{w l j}$ の部分で与えられる. 後者は式(19) で示されるように土地利用の違いが横流入水温に反映さ れるようになっている. その一方で，上・下流の滞留時 間の違いは現段階では考慮されていない。これより, 本 研究で対象とする揖保川流域では, 後述の結果のように このシンプルなモデルが良く機能しているが，規模が大 きな流域に適用する場合や，同一規模でも地質分布が大 きくちがう場合は，モデルの適用性の検討が必要となる. さらに, モデル内部で計算される各河道での基底流出量 と横流入水温・河川水温の関係や，流域各部での土地利 用と河川水温との関係については現段階では検討できて おらず，今後の課題となる.

\section{（2）河川水温ネットワークモデルの精緻化検証}

図-6は，基底流出水温モデルをネットワークモデルに 適用して推定した2007年11月の月平均河川水温の流域分 布である. 上流から河口までの全河道が推定水温に応じ
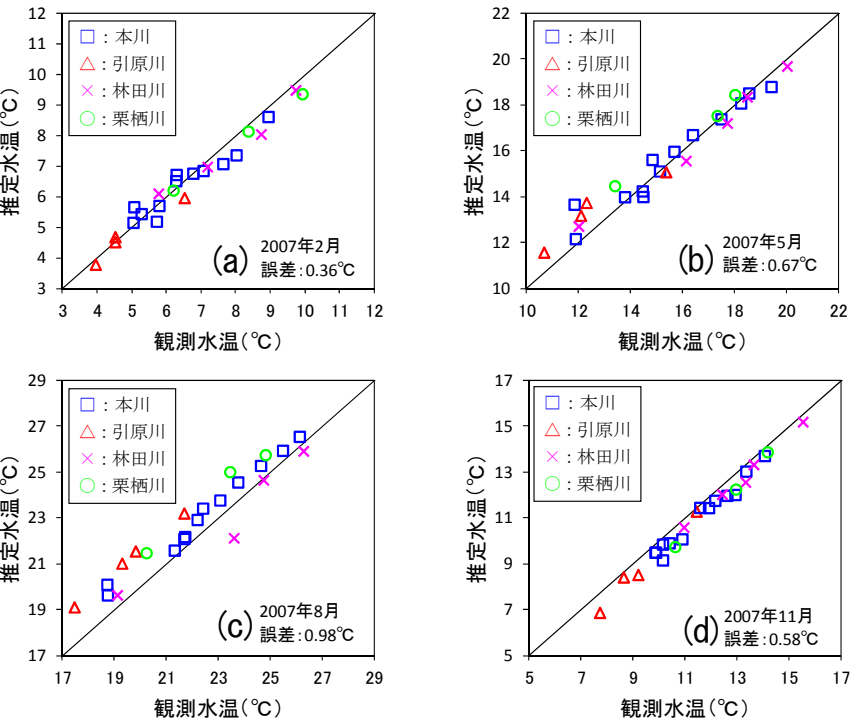

図-7 推定水温と観測水温の比較

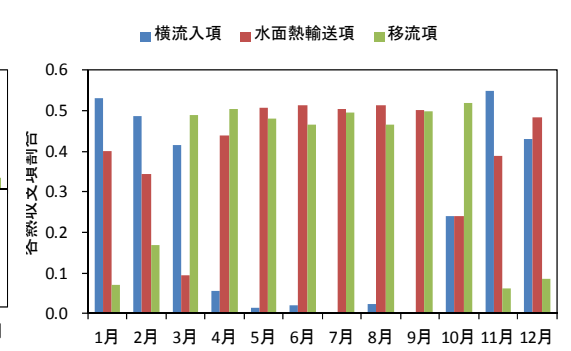

図-9 河川熱収支各項の割合

(本川下流 No. 16, 2007年)

て着色されており，観測点の位置する河道リンクでは推 定值を数字で示している. 図-1と比較すると, 推定值と 観測值が源流から下流まで全般的に非常によく一致して おり, 河川ネットワーク上を流下寸る過程での昇温構造 が良好に再現されている，これより，ピーク遅れをもつ 基底流出水温がネットワークモデルの水温予測性能を格 段に改善させたことが確認できる.

図-7に, 2007年2, 5, 8, 11月の推定水温と観測水温の比 較を示す，図では，揖保川本川と各支川を異なるシンボ ル・色でプロットし，さらに推定值と観測值の平均誤差 を付記した。

図-7より観測值と推定值を比較すると，どの季節にお いても $1^{\circ} \mathrm{C}$ 以内の平均誤差で全流域の河川水温が再現さ れており，本モデルの水温推定精度は非常に高いことが 確認できる. 特に, 前報1)まで課題となっていた放熱期 (11月)における水温は, 横流入水温モデルによる暖かい 水温流入で格段に精度が改善されている。一方，5月や8 月の受熱期では, 前報1) と比較して大きな変化は見られ なかった．このことより，放熱期では地下水流出の影響 が大きいのに対して，受熱期ではその影響が小さくなる と考えられる。

\section{（3）月平均河川水温の熱収支}

図-8，9に，月平均における式(11)各項のバランスおよ 
び，それぞれの項の占める割合を示す。ここでは2007年 の本川下流(No.16)のデータを示す．これらより，4月～9 月においては水面から河川への熱輸送が卓越する受熱期 であり，このとき水面熱輸送項と移流項がほぼつりあい， 基底流出水温の横流入はほぼ無視できる. したがって, 受熱期は水面からの熱フラックスと上流からの移流熱が 水系全体の水温を形成しているといえる。一方，11月〜 3月においては水面熱輸送項がマイナスを示し，放熱期 となる．このとき，基底流出水温の寄与を表す横流入項 がプラスの大きな值を示し，その影響が支配的になって 水系ネットワーク上の水温が形成されることが確認され る.

\section{5. 結 論}

本論文では，河川水温のネットワークモデルにおいて， 秋〜冬の放熱期の水温予測精度の改善を図るために，観 測事実により湧水・地下水の変動特性を取り入れた横流 入水温の数理モデルを構築した. 同定されたモデルパラ メーターより，揖保川では流域全域の平均として約3ヶ 月のピーク遅れをもつ年較差約 $14^{\circ} \mathrm{C}$ 基底流出があるこ とがわかった. この横流入水温モデルを導入した河川水 温ネットワークモデルは，す心゙ての季節で $1{ }^{\circ} \mathrm{C}$ 以下の精 度で月平均水温を推定できることが確認された．さらに, 得られたモデルより河川水温の熱収支を考察したところ， 受熱期には無視される横流入水温の影響が放熱期には水 系全体の水温形成に支配的な役割をもつことがわかった。

今後は, 確立された河川水温ネットワークモデルを用 いて，各河道における基底流出量と横流入水温・河川水 温の関係など詳細な水温形成機構を検討し, 河道網構造 や流域の土地利用変化が河川水系各部の水温に及ぼす影 響を検討する．さらに，物質循環モデル ${ }^{16)}$ と本ネット ワークモデルとのカップリングを図り，河川流域の生態 系代謝能が扱えるモデルに研究を発展させる予定である.

謝辞 : 本研究の実施にあたり, 費用の一部を科学研究費助成事業 (基艋研究(C), No.23510026)から補助して頂きました. 神戸大学教 授の道奥康治博士には常々，山梨大学准教授の市川温博士には昨 年の水工学講演会時に，それぞれ有益な御助言を頂きました. 水 温観測の実施にあたっては，国土交通省姫路河川国道事務所，兵 庫県龍野土木事務所，揖保川漁業組合の関係各位に便宜を図って 頂きました，以上，記して関係各位に謝意を表します。

\section{参考文献}

1) 前羽，宮本，中山:NDVIによる日射遮蔽と流量推定の補正によ る河川水温ネットワークモデルの改良, 土木学会論文集B1(水工 学),Vol.68,NNo.4, pp.I_733-I_738, 2012.

2) 宮本，前羽，中山，道奥: 日射遮蔽と流入水温の影響を補正し た河川水温ネットワークモデルの精㴛化,士木学会論文集B1(水 工学), Vol.67,No.4, pp.___1243-I_1248, 2011.
3) Miyamoto, H., Michioku, K., Maeba, H. and Nakayama, K.: A stream order network model for predicting basin-wide distribution of stream temperatures, Proceedings of the 34th IAHR World Congress, Proc. CDROM, 2011.

4) 宮本，菅原，道奥: 気候変動が流域の河川水温に及ぼす影響解 析, 水工学論文集, 第54巻,pp.1207-1212,2010.

5) 宮本，菅原，道奥: 上・中・下流域における河川水温の形成要因 に関寸る解析的検討, 水工学論文集, 第53巻,pp.1153-1158, 2009.

6) Miyamoto, H., Michioku, K. and Sugahara, Y.: Relative importance on each component in a thermal energy equation for stream temperature prediction, The 8th International Conference on Hydroscience and Engineering, Proc. CD-ROM, 2008.

7) 宮本, 道奥: 流域地形則を用いた河川水温分布モデル, 水工学 論文集，第52巻，pp.1069-1074， 2008.

8) 宮本, 道奥: 流域水温の連続観測と解析, 水工学論文集, 第51 巻, pp.1105-1110, 2007.

9) Miyamoto, H. and Michioku, K. Stream temperature observations and equilibrium temperatures in a river basin, Proceedings of the 32nd LAHR World Congress, Proc. CD-ROM, 2007.

10) 土木学会水理員会: 水理公式集, 平成11年度版, p.28, 1999.

11) Strahler, A.N.: Quantitative geomorphology of drainage basins and channel networks, in Handbook of Applied Hydrology, Chow, V.T. ed., Section 4-II, Geology, pp.4-39-4-76, McGraw Hill, 1964.

12) Shreve, R.L.: Infinite topologically random channel network, Journal of Geology, Vol.74, 1967.

13) 宮本, 石田, 道奥: 気象・地質・土地利用を考慮したリンク マグニチュードによる河川流量の推定モデル, 土木学会第66 回年次学術講演会, II-137,2011.

14) 新井, 西沢: 水温論, 297p, 共立出版, 1974.

15) Webb, B.W.: Trends in stream and river temperature, Hydrological Process, Vol.10, pp.205-226, 1996.

16) 戸田, 溝口, 野尻, 山下, 辻本: 河川連続体仮説と洪水パルス仮 説を統合した河川水系一貫物質循環解析, 水工学論文集, 第 57 巻(投稿中)

17) Sridhar, V. et al.: Prediction of stream temperature in forested watersheds, Journal of the American Water Resources Association, Vol.40, No.1, pp.197-213, 2004.

18) Chen, Y.D. et. al.: Stream temperature simulation of forested riparian areas: I. Watershed-scale model development, Journal of Environmental Engineering, ASCE, Vol.124, No.4, pp.304-315, 1998.

19) Chen, Y.D. et. al.: Stream temperature simulation of forested riparian areas: II. Model application, Journal of Environmental Engineering, ASCE, Vol.124, No.4, pp.316-328, 1998.

20) Theurer, F.D. et al: Interaction between riparian vegetation, water temperature, and salmonid habitat in the Tucannon river, Water Resources Bulletin, Vol.21, No.1, pp.53-64, 1985.

21) Stefan, H.G. and Sinokrot, B.A.: Projected global Climate change impact on water temperatures in five north central U.S. streams, Climate Change, Vol.24, pp.353-381, 1993.

22) 白岩, 風間, 沢本: 気候変動による河川水温の影響, 水工学 論文集，第50巻，pp.1063-1068，2006.

23) 近藤: 水環境の気象学, 350p, 朝倉書店, 1994.

(2012. 9. 30受付) 